\title{
Necrosis of muscle with carcinoma: myositis or myopathy?
}

\author{
H. URICH AND MARCIA WILKINSON \\ From The London Hospital, Stepney, London
}

SUMMARY A man aged 59 years developed a rapidly progressive muscular weakness which within a few weeks involved almost the entire musculature. A carcinoma of the stomach was discovered at necropsy. The skeletal muscles showed widespread necrosis with minimal inflammatory reaction. The findings are compared with those in a woman of 51 with Hashimoto's thyroiditis who developed a slowly progressive weakness of her trunk muscles which after some months began to involve the limbs. Post-mortem examination revealed typical polymyositis with massive inflammatory infiltration and limited necrosis of muscle. We conclude that these two types of muscle disease are morphologically, and probably pathogenetically, different.

Barbara Smith $(1968,1969)$ drew attention to the occurrence of necrosis of skeletal muscle associated with carcinoma without significant inflammatory reaction and which therefore did not conform with the pathological concept of polymyositis. Her observations were based on muscle biopsies of three cases associated with carcinoma of the colon, breast, and stomach. As conclusions based on small biopsies invite the criticism of being subject to sampling errors, we wish to support them by reporting a case in which two successive biopsies were followed by a detailed post-mortem study and comparing the findings with those in a typical case of polymyositis.

\section{CASE 1}

Necrotizing myopathy with carcinoma of the stomach.

CLINICAL HISTORY T.F., a mechanical engineer aged 59 years, was admitted to St. Margaret's Hospital, Epping, on 8 February 1967. Six weeks before admission he complained of pains in the lower part of the back which subsided after treatment with analgesics and physiotherapy. About four weeks before admission his legs became stiff. This stiffness gradually became worse and walking became progressively more difficult. He noticed increasing stiffness and weakness of his upper limbs and for 10 days had been in bed for most of the time. The day before entering hospital he had difficulty in swallowing. His appetite had decreased over the past two months with slight loss of weight.

On examination (8 February 1967) he was a fit-looking man, without cyanosis or clubbing of fingers. The res- piratory and cardiovascular systems and the abdomeno were normal. The blood pressure was $140 / 90 \mathrm{~mm} \mathrm{Hg}$ ? The cranial nerves were normal. In the motor system powef $\infty$ was generally diminished in the upper limbs, the weaknes $\$$ being most marked in the shoulders and $\mathrm{m}$. triceps. $\mathrm{f}_{\mathrm{O}} \mathrm{J}$ similar general weakness in the lower limbs was mosk $c$ marked proximally. There was generalized hypotonia@ the muscles were flabby on palpation, and no fasciculatio was seen. The reflexes were present and equal, the plantaㅎㅎ․ $\vec{v}$ responses flexor, and there was no sensory loss. He was unable to stand or sit up from the prone position in bed.

INVESTIGATIONS A blood count showed a haemoglobin of $114 \%$ and a white cell count of 8,600 per c.mm. The erythrocyte sedimentation rate was $63 \mathrm{~mm}$ in one hour. The plasma electrolytes and liver function tests were within normal limits. The serum enzyme estimations are summarized in Table 1 . Blood urea was $56 \mathrm{mg} / 100 \mathrm{ml}$. The cerebrospinal fluid was normal and the Wassermann reaction negative. A radiograph of the chest was normal.

Progress. During the week after admission he developed difficulty in swallowing and the pain and weakness of the muscles increased. By 13 February 1967 he had a weak hoarse voice, an impaired gag reflex, and the trapezii were noticed to be weak. The tongue was normal. Wasting of the limb girdles and the upper arm and thighs was conspicuous but no fasciculation was seen. He was put on prednisolone $10 \mathrm{mg}$ t.d.s. on 14 February 1967. Over the next two weeks the deterioration continued, he had more difficulty with swallowing, and his voice became weaker. A test dose of edrophonium on 16 February 1967 produced no improvement. On 20 February 1967 he was started on ACTH, 40 units daily, and after this there was minimal improvement as he could swallow some solid foods. However this was not maintained and by 6 March 1967 the muscular weakness had become more marked 
TABLE 1

ENZYME STUDIES: CASE 1

\begin{tabular}{|c|c|c|c|c|c|c|c|}
\hline & & 9 Feb. 67 & 24 Feb. 67 & 27 Feb. 67 & 2 March 67 & 6 March 67 & 9 March 67 \\
\hline & $\begin{array}{l}\text { (Normal } \\
\text { range) }\end{array}$ & & & * & & & \\
\hline $\begin{array}{l}\text { Serum alkaline phosphatase } \\
\text { (King-Armstrong u./100 ml.) }\end{array}$ & $(3-13)$ & $15 \cdot 2$ & & $36 \cdot 0$ & & $42 \cdot 0$ & \\
\hline $\begin{array}{l}\text { Serum acid phosphatase } \\
\text { (King-Armstrong u./100 ml.) }\end{array}$ & $(0-3)$ & $5 \cdot 0$ & & $2 \cdot 9$ & & $2 \cdot 6$ & \\
\hline $\begin{array}{l}\text { Serum tartrate labile acid phosphatase } \\
\text { (King-Armstrong u./100 ml.) }\end{array}$ & $\begin{array}{l}\text { (up to } \\
0.8)\end{array}$ & $2 \cdot 1$ & & $1 \cdot 1$ & & $0 \cdot 8$ & \\
\hline Serum adolase (i.u./l.) & $(0 \cdot 6)$ & $13 \cdot 0$ & & $22 \cdot 7$ & $20 \cdot 0$ & $20 \cdot 5$ & $20 \cdot 5$ \\
\hline Serum creatine phosphokinase (i.u./1.) & $(0-1 \cdot 0)$ & $9 \cdot 1$ & & $4 \cdot 0$ & $3 \cdot 5$ & $0 \cdot 3$ & $0 \cdot 3$ \\
\hline Serum lactic dehydrogenase (i.u./1.) & $(50-170)$ & 890 & 980 & & & & \\
\hline Serum $\alpha$-hydroxybutyric dehydrogenase (i.u./1.) & $(40-100)$ & 630 & 800 & & & & \\
\hline Serum glutamic-oxaloacetic transaminase (u.) & $(8-25)$ & 1280 & 84 & 392 & 236 & 244 & 250 \\
\hline
\end{tabular}

*Muscle biopsies 14 February 1967 and 1 March 1967.

and he was unable to lift his arms or use his hands. At this time he was noticed to have a firm, slightly enlarged tender liver with a lump on it. The deterioration continued and he died on 16 March 1967.

SUMMARY OF NECROPSY FINDINGS (LH PM No. App. 426/66) A carcinoma was present at the cardiac end of the stomach, with metastases in the liver, also in the coeliac, para-aortic, mediastinal, and left supraclavicular lymph nodes. Chylous ascites was present in the peritoneal cavity. The lungs showed early bronchopneumonia. Of the skeletal muscles, the sternomastoids, deltoids, rectus abdominis, psoas, sartorius, quadriceps, tibialis anterior, and parts of the erector spinae were strikingly pale. The pectoralis major, latissimus dorsi, triceps, oblique abdominal muscles, hamstrings, and calf muscles showed patchy pallor. No apparent lesions were seen in the small muscles of the hand or in the diaphragm. The brain, spinal cord, and major peripheral nerves were normal.

HISTOLOGY Stomach The tumour was a mucus-producing adenocarcinoma of variable degree of differentiation.

SKELETAL MUSCLES First biopsy (14 February 1967, right deltoid muscle, St. M. H. 279/67) There was considerable variation in size of muscle fibres, many of them being larger than normal. A few of the larger fibres showed central displacement of nuclei. There was no obvious necrosis of muscle, but a few fibres showed longitudinal splitting, while a few others were finely vacuolated (Fig. 1). In some bundles the fibres were widely separated by what appeared to be endomysial oedema, some of the wide subendomysial spaces con- taining homogeneous, eosinophilic material (Fig. 2). There was no cellular inflammatory reaction.

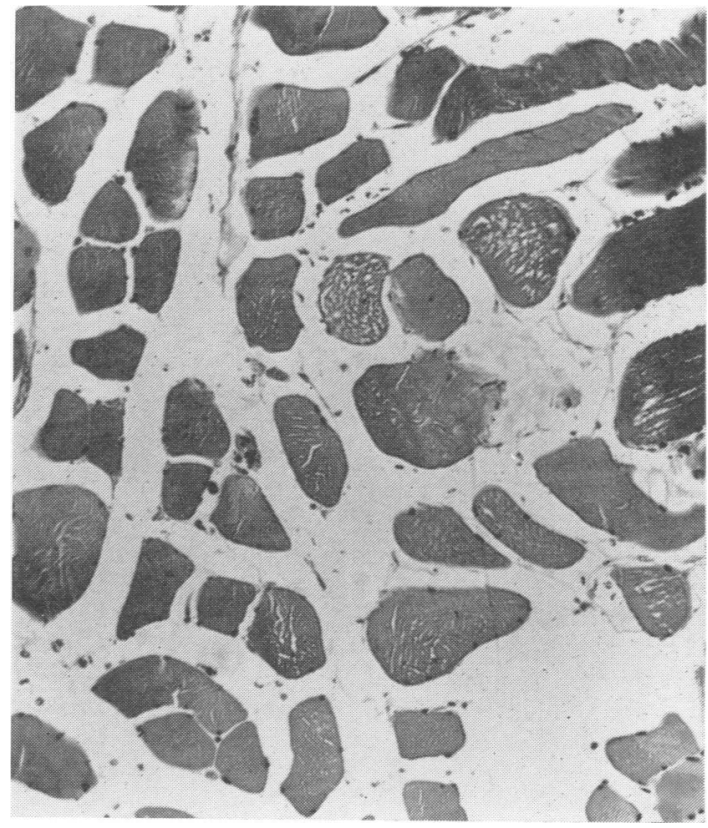

FIG. 1. Case 1. First biopsy: transverse section showing variation in size of muscle fibres and fine vacuolation. $H$ and $E, \times 165$. 


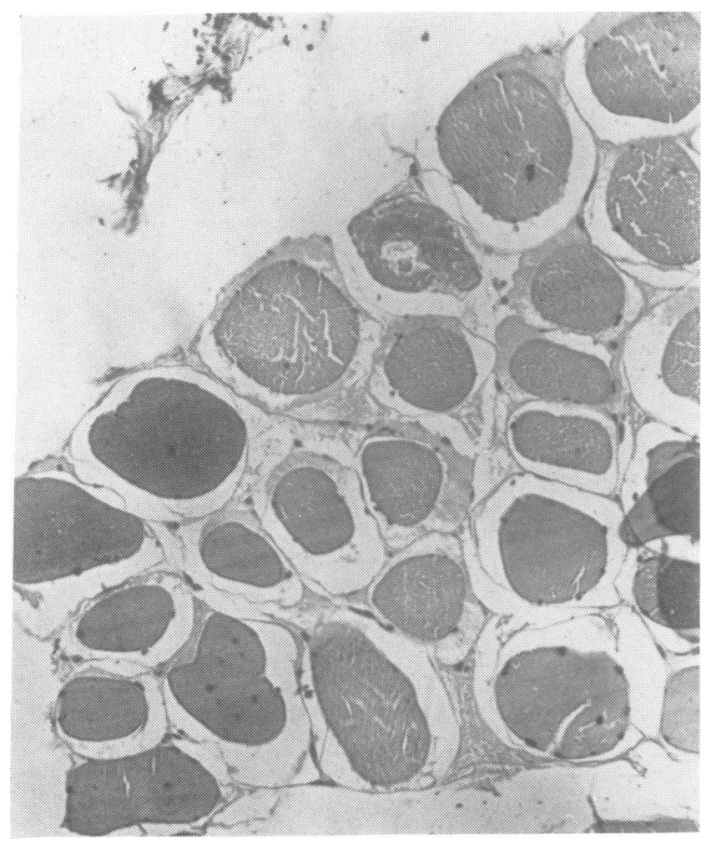

FIG. 2. Case 1. First biopsy: swelling of muscle fibres, central displacement of nuclei and endomysial oedema. $H$ and $E, \times 165$.

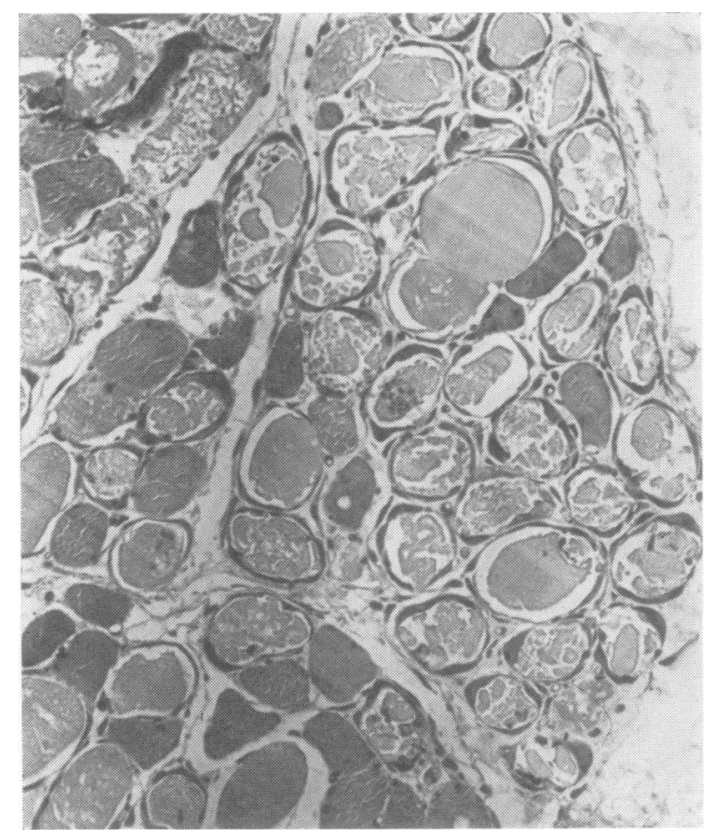

FIG. 3. Case 1. Second biopsy: necrosis and fragmentation of fibres with preservation of peripheral rim of sarcoplasm. $H$ and $E, \times 165$.

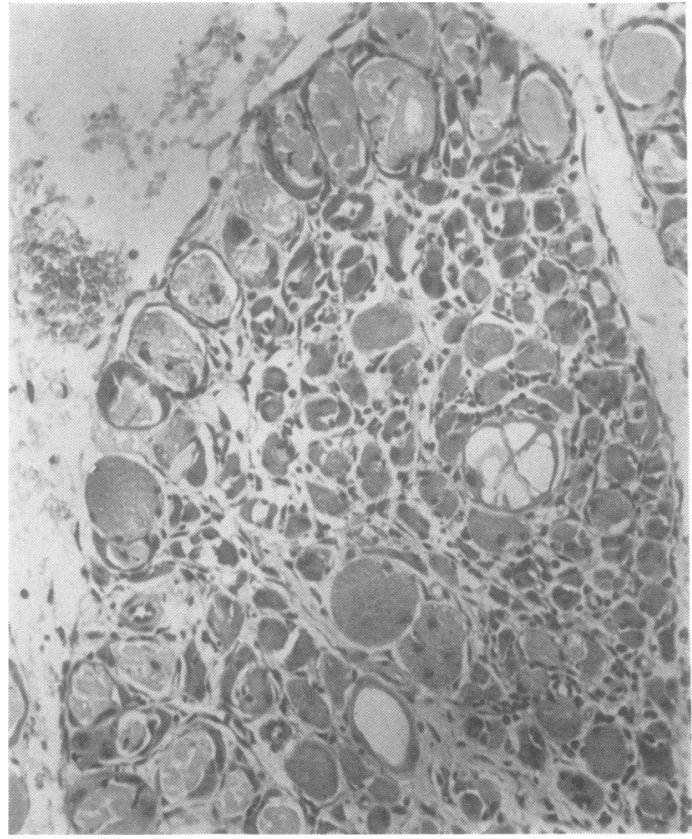

FIG. 4. Case 1. Second biopsy: coarse vacuolation and $\omega$ necrosis of fibres; the small fibres probably represent col $\stackrel{\circ}{\circ}$ lapsed sarcoplasmic remnants. $H$ and $E, \times 165$.

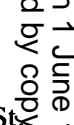

Second biopsy (1 March 1967, left deltoid muscle, St? M. H. 354/67) This showed massive necrosis of entire muscle bundles alternating with partially preserved ones The necrotic fibres were devoid of nuclei and generally in the stage of floccular or granular disintegration. There were several empty sarcolemmal tubes, some containing scanty eosinophilic debris. In many affected fibres a central zone of necrosis was surrounded by a thin, sometimes incomplete, ring of deeply basophilic sarcoplasm containing large vesicular nuclei resembling those seen in regenerating fibres which were also present in small numbers (Fig. 3). There was no phagocytosis, and no lymphocytic infiltration. In some areas there were groups of abnormally thin fibres, some obviously regenerating, other suggestive of sarcoplasmic remnants within collapsed sarcolemmal tubes (Fig. 4). The bundles of preserved fibres showed a variety of early degenerative changes, mainly hyalinization of the sarcoplasm or coarse vacuolation.

Necropsy With the exception of the tongue and diaphragm all muscles examined showed extensive fibre necrosis. In the most severely affected muscles which included the deltoid, sterno-mastoid, rectus abdominis, psoas, and sartorius muscles no normal tissue was seen. Large parts of these muscles showed diffuse fibrosis with numerous thin, filiform muscle fibres scattered among the collagen (Fig. 5). Those parts which contained large muscle fibres showed massive necrosis, mainly in the form of floccular or granular disintegration (Fig. 6). Basophilic 


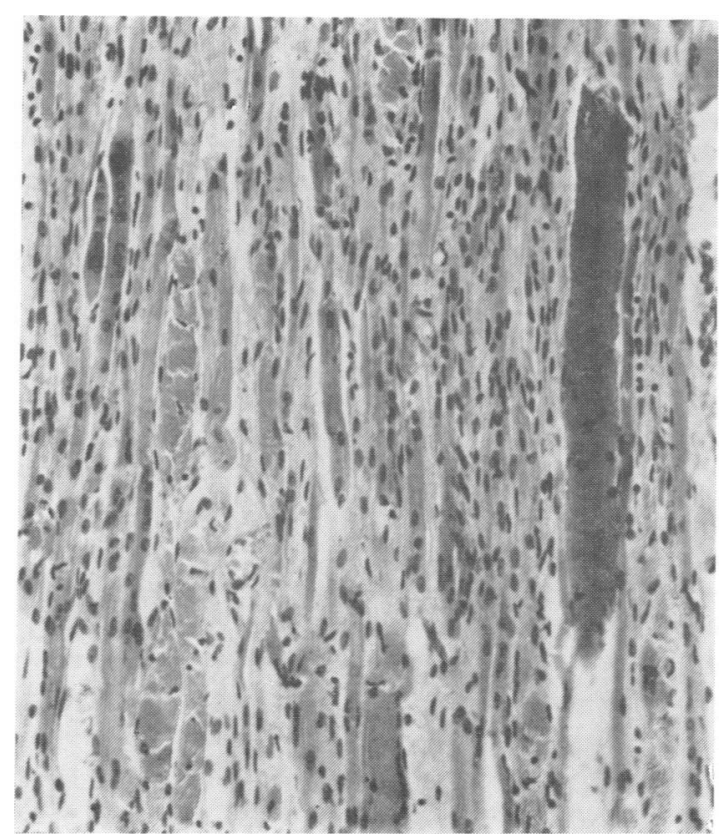

FIG. 5. Case 1. Necropsy, right deltoid muscle: atrophy of muscle fibres in areas of collagenous scarring; hyalinized and necrotic fibres also present. $H$ and $E, \times 165$.

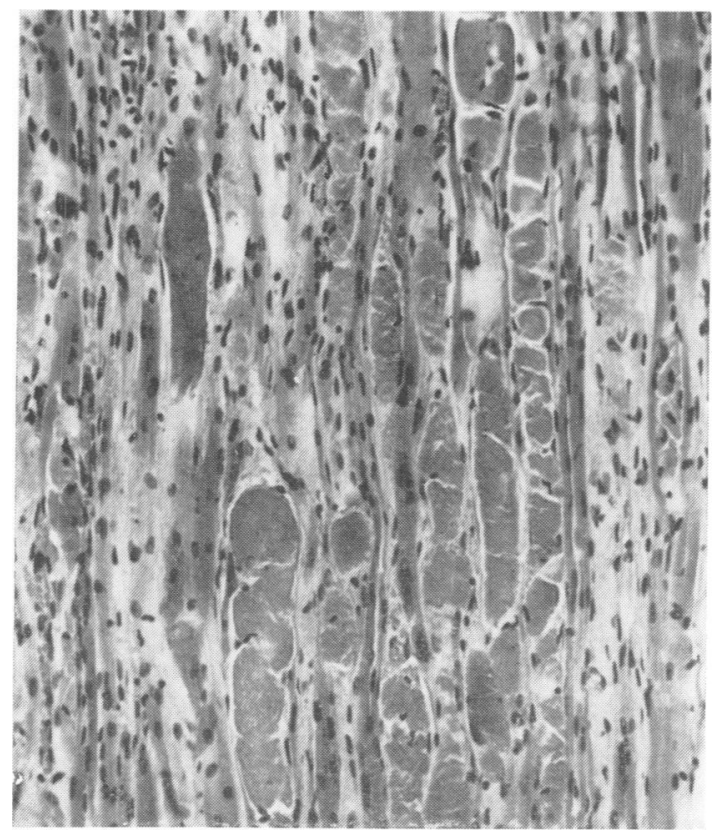

FIG. 6. Case 1. Necropsy, right deltoid muscle: massive necrosis and fragmentation of muscle fibres. $H$ and $E$, $\times 165$.

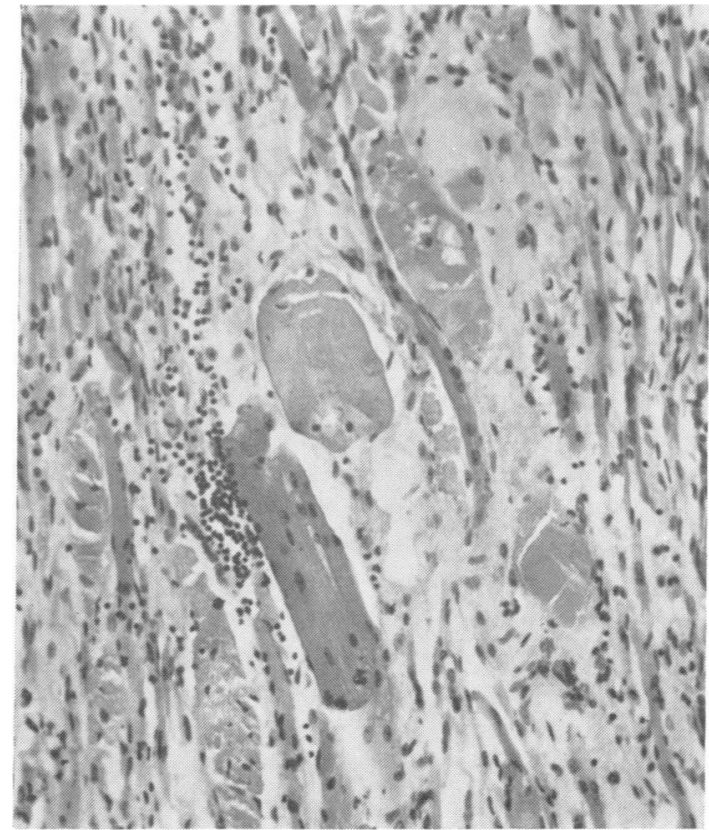

FIG. 7. Case 1. Necropsy, right quadriceps muscle: sparse lymphocytic infiltration in severely damaged tissue. $H$ and $E, \times 165$.

regenerating fibres were present, but subsarcolemmal basophilic masses were scanty. The triceps, quadriceps, and tibialis anterior muscles showed massive necrosis, but with minimal scarring. The pectoralis major, biceps femoris, gastrocnemius, erector spinae, abductor pollicis brevis, and abductor digiti minimi muscles resembled the second biopsy in that they showed bundles of necrotic muscle fibres alternating with relatively wellpreserved bundles. The latter showed some degree of gener alized non-specific wasting as well as minor degenerative changes such as hyalinization or vacuolation of a small propoltion of fibres. Phagocytosis of necrotic muscle fibres was not conspicuous in any section examined. Many, though not all, affected muscles showed a sparse sprinkling with lymphocytes which in some places formed small aggregates (Fig. 7). Only one vessel in all the sections was cuffed by a small cluster of lymphocytes (Fig. 8).

CASE 2

Subacute polymyositis with Hashimoto's thyroiditis.

CLINICAL HISTORY E.K., a housewife aged 51 years, was admitted to the Elizabeth Garrett Anderson Hospital on 2 August 1962 (Rec. No. M. 867). Five months previously she had developed difficulty in swallowing and her speech became 'blurry'. She had also noticed difficulty in holding her head up particularly when walking, had no energy, and became easily breathless. Two months later she attended the out-patient department because of these symptoms and of a lump in her neck. This swelling 


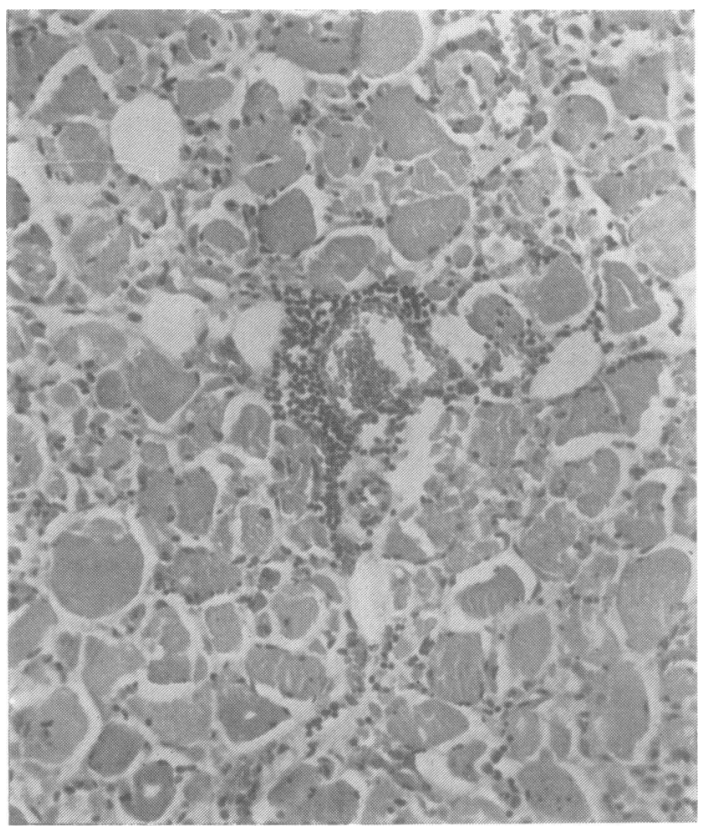

FIG. 8. Case 1. Necropsy, right biceps femoris muscle: small perivascular aggregation of lymphocytes in necrotic muscle. $H$ and $E, \times 165$.

decreased after she was given sodium thyroxine $0.2 \mathrm{mg}$ daily. However, the difficulty in swallowing became worse and at the time of admission she was able to swallow fluids but choked over solids. On examination she looked well, and no finger clubbing or cyanosis was seen. The cardiovascular, respiratory, and alimentary systems were normal. The thyroid was diffusely enlarged. The blood pressure was $120 / 80 \mathrm{~mm} \mathrm{Hg}$. She spoke with a nasal voice and slurred her words, but her tongue and other cranial nerves were normal. There was no weakness or wasting of muscles of the limb girdles. The reflexes were present and equal. On 20 September 1962 she was found to have some weakness of the muscles of mastication and of the palate with marked weakness of the sternomastoids and trapezii. There was no wasting of the tongue. She also had marked proximal weakness of both upper limbs but distally the power was reasonably good. No sensory loss was found and the reflexes were normal.

She was discharged on 3 October 1962 but readmitted on 14 November 1962 having deteriorated considerably. On examination at this time there was marked weakness of the facial muscles, muscles of mastication, sternomastoid, trapezius, biceps, triceps, spinal extensors, and intercostal muscles. Speech was almost unintelligible and she could not close her mouth. She could swallow fluids only and had lost a considerable amount of weight. Her condition steadily deteriorated and she died on 19 November 1962.

INVESTIGATIONS (19 May 1962) The thyroid complement fixation test was moderately strong (titre 1/64). The tanned red cell agglutination test was weakly positive (titre 1/250). The fluorescent tests against thyroid colloid and thyroid cytoplasm were strongly positive. The results suggested Hashimoto's disease.

Her haemoglobin was $11.5 \mathrm{~g} / 100 \mathrm{ml}$. and her white cell count $4,400 /$ c.mm. The erythrocyte sedimentation rate was $28 \mathrm{~mm}$ in one hour.

30 July 1962. Barium swallow: thin barium passed down the oesophagus without delay but barium cream distended the hypopharynx and only a narrow stream passed down the oesophagus. Spill-over then occurred into the larynx and trachea. No organic obstruction was seen in the upper oesophagus and the impression gained was that of neuromuscular incoordination.

13 September 1962. The electromyogram of the left trapezius muscle showed a poor interference pattern with motor unit potentials of abnormally short duration. No electromyographic activity was found in the spinal extensors in the upper dorsal region. The findings were suggestive of a myopathy.

19 November 1962. The cerebrospinal fluid was normal. Reiter's protein complement fixation test was negative.

19 November 1962 . The blood urea was $20 \mathrm{mg} / 100 \mathrm{ml}$.

21 November 1962. Complement fixation tests against human skeletal muscle and brain were negative.

SUMMARY OF NECROPSY FINDINGS (LH PM No. App. $519 / 61$ ) The thyroid showed a lymphadenoid goitre with scattered colloid adenomata. There was mild splenomegaly with follicular hyperplasia. The thymus was apparently normal. The skeletal muscles showed widespread pallor of irregular distribution, the following muscles being severely affected: trapezius, latissimusg dorsi, erectol spinae, psoas, diaphragm, rectus abdominis, and medial head of gastrocnemius. Other muscles appeared either normal or showed minimal patchy dis-? colouration. The central and peripheral nervous system were normal.

HISTOLOGY Thyroid There was extensive lymphocytic infiltration with formation of lymphoid follicles containing germinal centres. Partial destruction of parenchyma had occurred. Islands of Askanazy cells and patches of fibrosis were present. A colloid adenoma was unaffected by the inflammatory process.

SKELETAL MUSCLES Biopsy (25 September 1962, left trapezius muscle, EGA 891/62) The muscle showed severe, almost total fibrosis. Scanty muscle fibres survived among the strands of collagen, most of them abnormally thin. Some were reduced to chains of clumped sarcolemmal nuclei. A few fibres were deeply eosinophilic and hyalinized, but none showed frank necrosis or phagocytosis. Scanty basophilic fibres with large vesicular nuclei were also present. There was prominent lymphocytic infiltration, mainly perivascular, but in places extending deeply into the collagen between the surviving muscle fibres (Fig. 9).

Necropsy The most constant feature in all affected muscles was the presence of inflammatory infiltration, both perivascular and diffuse (Figs. 10 and 11). It con- 


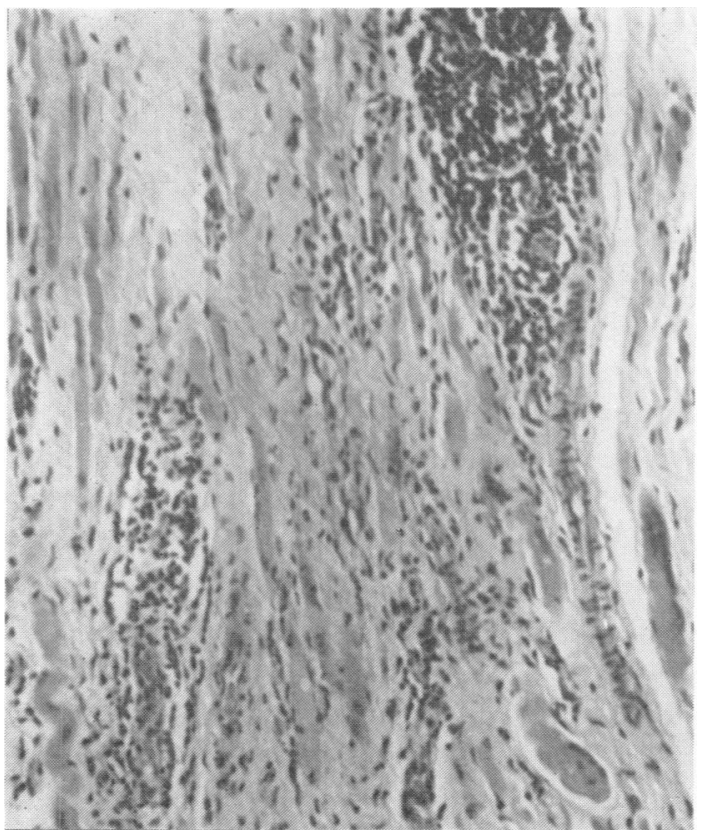

FIG. 9. Case 2. Biopsy: almost total scarring with survival of scanty atrophic muscle fibres and heavy lymphocytic infiltration. $H$ and $E, \times 165$.

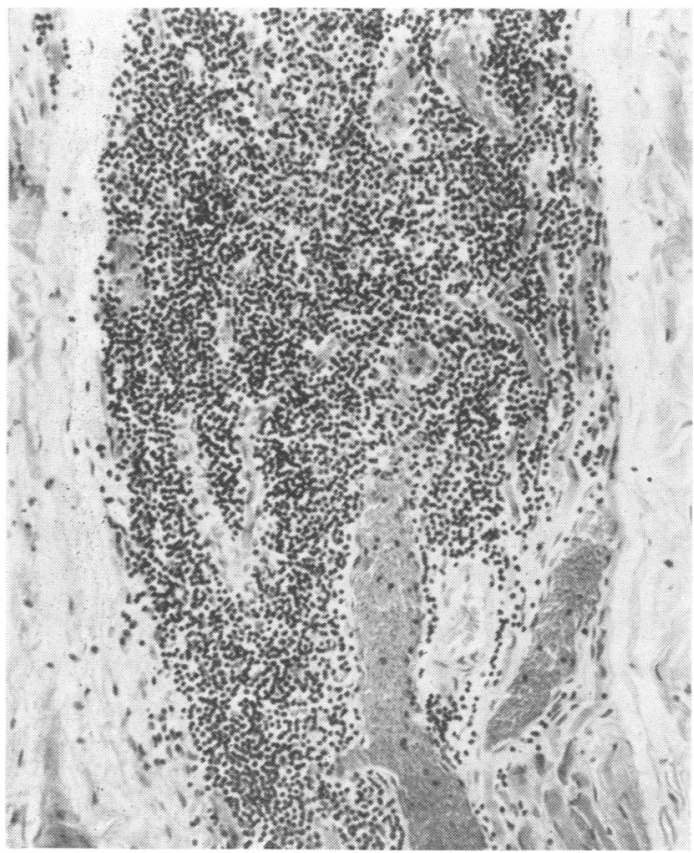

FIG. 10. Case 2. Necropsy, right trapezius muscle: massive perivascular lymphocytic infiltration. $H$ and $E, \times 165$

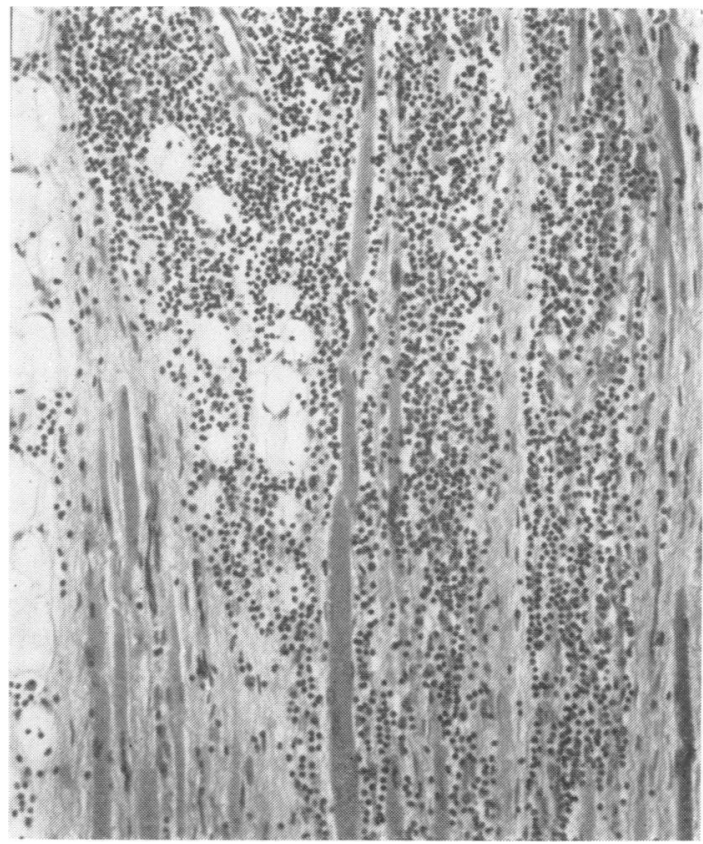

FIG. 11. Case 2. Necropsy, right rectus abdominis muscle: diffuse interstitial lymphocytic infiltration. $H$ and $E, \times 165$

sisted predominantly of small lymphocytes with an admixture of a few plasma cells. The degree of damage to muscle fibres varied considerably. In the most severely affected muscle ( $m$. erector spinae) there was extensive loss of muscle fibres with replacement by fat or collagen (Fig. 12). The surviving fibres were mostly severely atrophic and showed crowding and clumping of nuclei. Other severely affected muscles (trapezius, latissimus dorsi, rectus abdominis, diaphragm, psoas, and medial head of gastrocnemius) showed marked variation in fibre size ranging from thin, filiform fibres to abnormally large ones, often with central nuclei. Crowding and clumping of nuclei in atrophic fibres was conspicuous in places. Degenerative changes in the larger fibres included hyalinization and vacuolation. Necrotic fibres were scanty, the process usually involving short segments only. Only in one muscle, the psoas, was necrosis and phagocytosis fairly extensive (Fig. 13). There was little evidence of regeneration. Fibrosis was present in all severely affected muscles, patchy in some, diffuse in others. Similar, but more patchy, changes, with preservation of unaffected areas, were found in the pectoralis major, abductor pollicis brevis, and the tongue muscles. The deltoid and sternomastoid muscles showed inflammatory infiltration with some variation in fibre size. Focal aggregations of lymphocytes in otherwise normal muscle were present in the $\mathrm{m}$. biceps brachii and the lateral head of the $\mathrm{m}$. gastrocnemius (Fig. 14). No lesions were found in the quadriceps or biceps femoris muscles. 


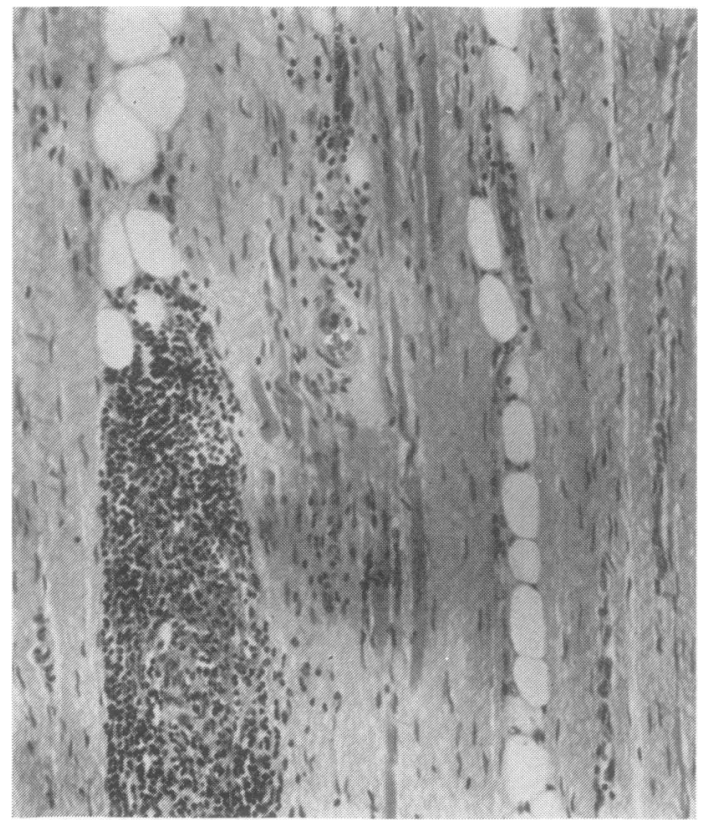

FIG. 12. Case 2. Necropsy, right erector spinae muscle: persistent lymphocytic infiltration in almost totally destroyed and scarred muscle. $H$ and $E, \times 165$.

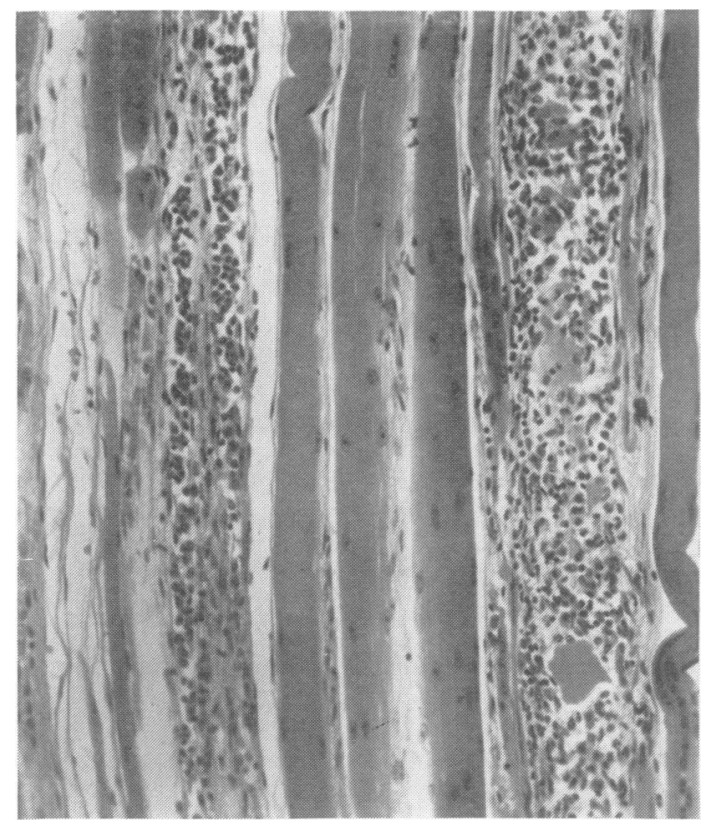

FIG. 13. Case 2. Necropsy, right psoas muscle: necrosis and phagocytosis of muscle fibres. $H$ and $E, \times 165$.

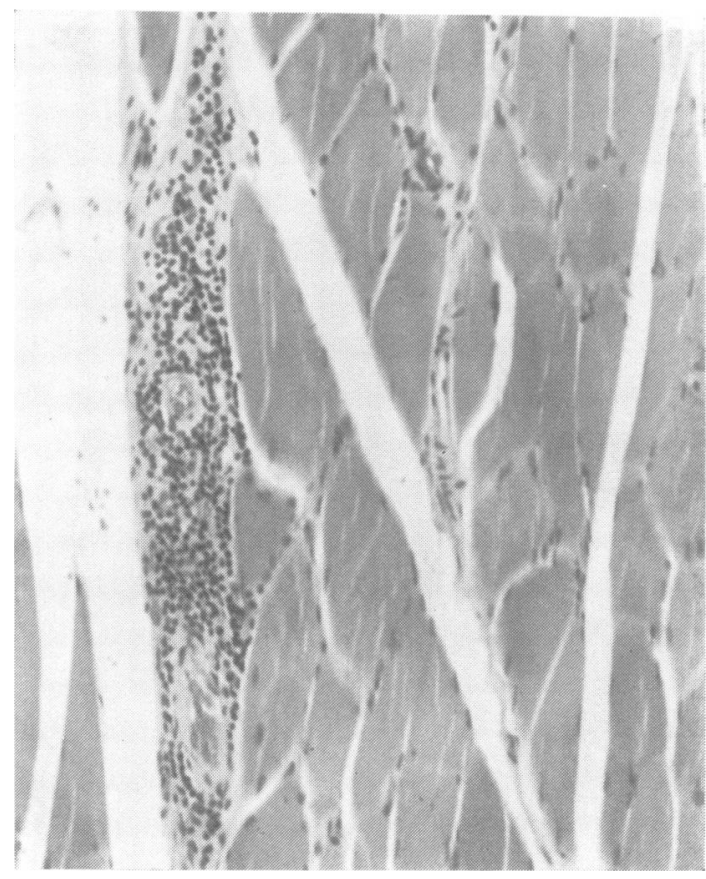

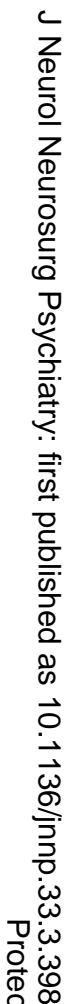

FIG. 14. Case 2. Necropsy, lateral head of right gastrocnemius muscle: perivascular cuffing in otherwise normato muscle. $H$ and $E, \times 165$.

\section{DISCUSSION}

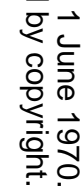

In an attempt to compare the necrotizing muscle disease of carcinoma with typical polymyositis we have deliberately chosen an example of the latter condition associated with Hashimoto's thyroiditis. The unusual association with a well-established autoimmune disease adds circumstantial evidence to the now widely accepted view of the hyperimmune nature of polymyositis. The comparison of two single cases obviously permits only very limited general conclusions and the final verdict on the similarity or otherwise of the two conditions will depend on the analysis of a larger series of cases, not available at present. Certain features in the two cases are nevertheless sufficiently different to be of some significance.

Case 1 is unusual clinically in that there was a very rapid progression of muscular weakness and wasting over a period of seven weeks. Until the end of January 1967 his main complaint was of stiffness in his legs but he was able to get about normally. Ten days later, when he was admitted, he was able to walk only with assistance and was unable to sit up in bed unaided. From then on there was a rapid progression of the weakness and wasting. This deterior- 
ation is reflected in the findings of the muscle biopsies. The first, on 14 February 1967, showed minimal changes only (Figs. 1 and 2), while the second, on 1 March 1967, was grossly abnormal (Figs. 3 and 4). The abnormalities of muscle enzymes, especially SGOT and creatine phosphokinase, were particularly marked in the early stages.

In case 2 the disorder of muscle developed much more slowly as the weakness, first apparent in the neck and in the muscles of deglutition in April 1962, did not spread to the shoulder girdle until September. At that time a biopsy of the trapezius muscle showed already advanced changes (Fig. 9). From then on the muscular weakness and wasting progressed until her death in November 1962.

Turning to the pathological aspects of the two cases three features merit discussion: the necrosis of muscle fibres, the inflammatory infiltration, and the topography of the lesions. There is a striking contrast between the massive necrosis involving entire muscle bundles in case 1 and the sparse, mostly segmental, necrotic lesions in case 2 . Preservation of the sarcolemma and apparent subsarcolemmal regeneration of the sarcoplasm were also prominent in our first case as they were in Smith's (1968) third patient. These features led her to the interesting hypothesis that in necrosis of muscle with carcinoma the primary damage was to the sarcoplasm, while in polymyositis the fibre was attacked from without through the sarcolemma. The striking absence or paucity of phagocytosis in the former condition lends support to this view, the inference being that macrophages cannot penetrate through the intact sarcolemma while they readily invade the dead fibres in polymyositis. No doubt ultrastructural studies will throw further light on the behaviour of the sarcolemma in these two types of muscular disease.

The other important difference between the two cases lies in the degree of inflammatory infiltration. This was particularly striking in minimal, presumably early, lesions. In our second case aggregates of lymphocytes were present in some otherwise apparently normal muscles. Lymphocytic infiltration, both perivascular and diffuse, was intense in severely affected muscles and persisted even in areas of almost total destruction. By contrast the early lesions in case 1 were devoid of lymphocytes which remained sparse even in severely damaged tissue. This paucity of inflammatory reaction cannot be ascribed to disappearance of the infiltrate in a burnt-out process or to its reduction by immunosuppressive therapy as it was absent in the first biopsy taken during an active stage of the disease before effective treatment with steroids. These observations may have some implications on pathogenesis, as the findings in case 2 are consistent with an immune reaction mediated by cell-bound antibodies, while those in case 1 are unlikely to be caused by a similar mechanism.

The comparison of the topography of lesions in the two cases leads to less valid conclusions. In both patients the proximal muscles were most severely affected, but this is a feature common to most myopathies. As far as can be ascertained from macroscopic appearances the lesions were symmetrical, at least in the trunk.

There was a general impression of a more diffuse involvement of the musculature in case 1 and a more random distribution in case 2 with several major muscle groups escaping. On the other hand, the tongue and diaphragm were intact in our first patient and severely affected in the second. All these differences may represent only individual variations and will require further studies on a larger series of cases.

It is difficult to decide on the available evidence whether the two conditions here illustrated represent two ends of the same spectrum or two different nosological entities. The association of destructive lesions of muscle, 'dermatomyositis' or 'polymyositis', with malignant neoplasms first reported by Stertz (1916) and established by Bezecny (1935) and Scheuermann (1951) is probably less common than is generally believed. According to Rowland and Schotland (1965) only about $12 \%$ of cases of dermatomyositis occur in conjunction with carcinoma. Few cases are histologically well documented and a review of the literature undertaken by Smith (1969) showed that most of them belong to the necrotizing rather than the inflammatory group (see Table 2). It is of interest that Walton and Adams (1958) regarded the association of inflammatory disease of muscle with neoplasms in their cases 35 and 36 as probably fortuitous.

The justification for grouping both types of case under the generic term 'polymyositis' may be open to question. McCombs and MacMahon (1947) interpreted the findings in their case as serous inflammation and therefore legitimately called it 'acute myositis'. The concept of serous inflammation, although probably valid theoretically, has the drawback of not being readily identifiable in histological sections. The allocation of a process to this group thus becomes a matter of interpretation rather than observation. This is well borne out by Scheuermann's changing views on the pathogenesis of dermatomyositis without cellular infiltration: in 1939 he favoured the theory of serous inflammation, in 1958 he interpreted the same lesions as purely degenerative and non-inflammatory. If cases of the necrotizing type are included in the group of 'polymyositis', there is little doubt that they form a 
TABLE 2

ANALYSIS OF WELL-DOCUMENTED CASES OF DESTRUCTIVE MUSCULAR DISEASE WITH NEOPLASMS

\begin{tabular}{|c|c|c|c|c|c|}
\hline Authors & Sex, age & Primary tumour & $\begin{array}{l}\text { Nature of } \\
\text { material }\end{array}$ & Type of lesion & Comment \\
\hline Kankeleit (1916) & F 38 & Breast & Necropsy & $\begin{array}{c}\text { Necrotizing } \\
\text { (sparse lymphocytic infiltration) }\end{array}$ & $\begin{array}{l}\text { Description only, } \\
\text { no illustrations }\end{array}$ \\
\hline Bezecny (1934-5) Case 2 & F 41 & Breast & Necropsy & $\begin{array}{l}\text { 'Degenerative and oedematous' } \\
\text { (sparse lymphocytic infiltration) }\end{array}$ & $\begin{array}{l}\text { Description only, } \\
\text { no illustrations }\end{array}$ \\
\hline $\begin{array}{l}\text { Sheldon, Young, and } \\
\text { Dyke (1939) }\end{array}$ & M 17 & $\begin{array}{l}\text { 'Reticulo-endothelioma' } \\
\text { (? reticulum-cell sarcoma) }\end{array}$ & Necropsy & $\begin{array}{l}\text { Probably necrotizing } \\
\text { (some plasma cell infiltration) }\end{array}$ & $\begin{array}{l}\text { Description only, } \\
\text { no illustrations }\end{array}$ \\
\hline $\begin{array}{l}\text { McCombs and MacMahon } \\
\text { (1947) (also Walton and } \\
\text { Adams, case 38) }\end{array}$ & M 55 & $\begin{array}{l}\text { Bronchus } \\
\text { (oat cell) }\end{array}$ & Necropsy & Necrotizing & \\
\hline Cottel (1952) Case 1 & M 50 & Stomach & Necropsy & Necrotizing & $\begin{array}{l}\text { 'Diffuse lymphocytic } \\
\text { infiltration' } \\
\text { in description, }\end{array}$ \\
\hline Case 2 & M 58 & Kidney & Necropsy & Necrotizing & $\begin{array}{l}\text { apparently sparse in } \\
\text { illustrations }\end{array}$ \\
\hline \multicolumn{6}{|l|}{ Walton and Adams, (1958) } \\
\hline Case 35 & F 44 & Hodgkin & Biopsy & Inflammatory & ? fortuitous \\
\hline Case 36 & F 52 & Colon & Biopsy & Inflammatory & association \\
\hline Case 37 & M 65 & Prostate & Biopsy & $\begin{array}{c}\text { Necrotizing } \\
\text { (small foci of lymphocytes) }\end{array}$ & \\
\hline $\begin{array}{l}\text { Case } 39 \\
\text { Case } 40\end{array}$ & $\begin{array}{r}\text { F } 65 \\
\text { M } 65\end{array}$ & $\begin{array}{l}\text { Gall bladder } \\
\text { Bronchus } \\
\text { (oat cell) }\end{array}$ & $\begin{array}{l}\text { Necropsy } \\
\text { Biopsy }\end{array}$ & $\begin{array}{l}\text { Necrotizing } \\
\text { Necrotizing }\end{array}$ & \\
\hline \multicolumn{6}{|l|}{$\begin{array}{l}\text { Scherbel, McCormack, } \\
\text { Mackenzie, and Atdjian } \\
\text { (1964) }\end{array}$} \\
\hline $\begin{array}{l}\text { Case } 1 \\
\text { Case } 6\end{array}$ & $\begin{array}{r}\text { M } 55 \\
\text { F } 59\end{array}$ & $\begin{array}{l}\text { Prostate } \\
\text { Breast }\end{array}$ & $\begin{array}{l}\text { Biopsy } \\
\text { Biopsy }\end{array}$ & $\begin{array}{l}\text { Inflammatory } \\
\text { ? Necrotizing } \\
\text { ? Non-specific }\end{array}$ & $\begin{array}{l}\text { Illustrations only, } \\
\text { no description }\end{array}$ \\
\hline $\begin{array}{l}\text { Smith }(1968,1969) \\
\text { Case } 1\end{array}$ & F 54 & Colon & Biopsy & $\begin{array}{c}\text { Necrotizing } \\
\text { (scanty lymphocytes) }\end{array}$ & \\
\hline $\begin{array}{l}\text { Case } 2 \\
\text { Case } 3 \\
\text { Holt and Azzopardi (1969) } \\
\text { Present case } 1\end{array}$ & $\begin{array}{r}\text { F } 60 \\
\text { F } 48 \\
\text { F } 42 \\
\text { M } 59\end{array}$ & $\begin{array}{c}\text { Breast } \\
\text { Stomach } \\
\text { Plasmacytoma of stomach } \\
\text { Stomach }\end{array}$ & $\begin{array}{l}\text { Biopsy } \\
\text { Biopsy } \\
\text { Necropsy } \\
\text { Biopsy and } \\
\text { Necropsy }\end{array}$ & $\begin{array}{l}\text { Necrotizing } \\
\text { Necrotizing } \\
\text { Necrotizing } \\
\text { Necrotizing }\end{array}$ & (1968 paper only) \\
\hline
\end{tabular}

separate sub-group. In the comment on their case 39 Walton and Adams (1958) state: 'The absence of inflammatory cell infiltrates in the muscle suggests that this type of polymyositis may possibly be of toxic or metabolic, rather than of allergic origin'. We concur with this conclusion and would therefore prefer a more non-committal term such as 'necrotizing myopathy', instead of 'polymyositis' with its inflammatory implications.

It may be added that necrotizing myopathy is not confined to cases associated with malignant tumours. A substantial group of patients with clinically typical primary 'dermatomyositis' show predominantly degenerative lesions in their skeletal muscles with a negligible inflammatory component (McLetchie and Coward, 1957; Scheuermann, 1958). Further detailed studies on biopsy and necropsy material will be necessary to establish a clear-cut separation of the essentially degenerative from the primarily inflammatory diseases of muscle.

Finally some comment is required on the noso- logical position of necrotizing muscular disease within the group of carcinomatous myopathies. In their classification of non-metastatic neurological disease associated with neoplasms, Brain and Adams (1965) divided muscular disorders into four groups: (1) polymyopathy, (2) disorders of neuromuscular transmission, (3) polymyositis and dermatomyositis, and (4) metabolic myopathies secondary to disordered endocrine function. Cases of necrotizing myopathy have been included in the third group, thus blurring the distinction between 'polymyopathy' and 'polymyositis'. The inclusion of necrotizing myopathy in the first group of Brain and Adams would necessitate subdivision of this group into two groups: (a) atrophic, (b) necrotizing. The two types are distinct morphologically, the atrophic variety being characterized by wasting of individual muscle fibres indistinguishable from that seen in cachexia from any cause. Fibre necrosis, if present at all, is sparse and inconspicuous (Henson, Russell, and Wilkinson, 1954). Too little is known about the 
mechanism of degenerative processes in muscle to postulate any pathogenetic links between these two types of myopathy.

While on purely pathological criteria such a regrouping may appear desirable, clinical considerations would favour the retention of the Brain and Adams classification, however heterogeneous the group of 'polymyositis' may be morphologically and pathogenetically. Until the nosology of this group is clarified, there is little to be gained from an alternative scheme of classification, but every effort should be made to allocate each case to its appropriate histological sub-group.

We should like to thank Dr. M. E. Morgans and Dr. H. Kopelman for permission to publish their cases, and Dr. I. M. Tuck and Dr. B. J. Haram for allowing us access to their biopsy material. We are grateful to Dr. R. Sarnaker for her help in the preparation of sections. We are indebted to the British Empire Cancer Campaign without whose grant this work would not have been possible.

\section{REFERENCES}

Bezecny, R. (1934-1935). Dermatomyositis. Arch. Derm. Syph. (Berl.), 171, 242-251.

Brain, Lord, and Adams, R. D. (1965). A guide to the classification and investigation of neurological disorders associated with neoplasms in The Remote Effects of Cancer on the Nervous System, pp. 216-221. Edited by Lord Brain and F. H. Norris, Grune and Stratton: New York.

Cottel, C. E. (1952). Dermatomyositis and malignant neoplasm. Amer. J. med. Sci., 224, 160-168.

Henson, R. A., Russell, D. S., and Wilkinson, M. (1954). Carcinomatous neuropathy and myopathy: a clinical and pathological study. Brain, 77, 82-121.
Holt, L. P. J., and Azzopardi, J. G. (1969). A case of gastric ulcer and dermatomyositis demonstrated at the Royal Postgraduate Medical School (clinicopathological conference) [and ensuing discussion]. Brit. med. J., 4, 221-225.

Kankeleit (1916). Über primäre nichteitrige Polymyositis. Dtsch. Arch. klin. Med., 120, 335-349.

McCombs, R. P., and MacMahon, H. E. (1947). Dermatomyositis associated with metastasizing bronchogenic carcinoma. A clinicopathological conference. Med. Clin. N. Amer., 31, 1148-1162.

McLetchie, N. G. B., and Coward, N. B. (1957). Dermatomyositis. Canad. med. Ass. J., 76, 1018-1029.

Rowland, L. P., and Schotland, D. L. (1965). Neoplasms and muscle disease in The Remote Effects of Cancer on the Nervous System, pp. 83-97. Edited by Lord Brain and F. H. Norris. Grune and Stratton: New York.

Scherbel, A. L., McCormack, L. J., Mackenzie, A. H., and Atdjian, M. (1964). Association of certain connective tissue syndromes and malignant disease. Postgrad. Med. J., 35, 619-628.

Scheuermann, H. (1938-1939). Zur Klinik und Pathogenese der Dermatomyositis (Polymyositis). Arch. Derm. Syph. (Berl.), 178, 414-468.

Scheuermann, H. (1950-1951). Maligne Tumoren bei Dermatomyositis und progressiver Sklerodermie. Arch. Derm. Syph. (Berl.), 192, 575-582.

Scheuermann, H. (1958). Dermatomyositis. Ergebn. inn. Med. Kinderheilk., 10, 427-480.

Sheldon, J. H., Young, F., and Dyke, S. C. (1939). Acute dermatomyositis associated with reticulo-endotheliosis. Lancet, 1, 82-84.

Smith, B. (1968). Skeletal muscle necrosis associated with carcinoma. In Research in Muscular Dystrophy: Proceedings of the 4th Symposium on Current Research in Muscular Dystrophy. pp. 255-261. Edited by the Research Committee of the Muscular Dystrophy Group. Pitman: London.

Smith, B. (1969). Skeletal muscle necrosis associated with carcinoma. J. Path., 97, 207-210.

Stertz (1916). Polymyositis. Berl. klin. Wschr., 53, 489.

Walton, J. N., and Adams, R. D. (1958). Polymyositis, pp. 236-244. Livingstone: Edinburgh. 